\title{
Analysis of Effects of Selected Aerosol Particles to the Global Climate Change and Health using Remote Sensing data: The Focus on Africa
}

\author{
Rushingabigwi, G. ${ }^{* 1,2}$, Kalisa, W. ${ }^{2}$, Nsengiyumva, . $^{1}$, Zimulinda, F. ${ }^{1}$, Muk anyiligira, D., \\ Sibomana, L. ${ }^{1}$ \\ 1. University of Rwanda, College of Science and Technology, P.O Box: 3900 Kigali, Rwanda \\ 2. Remote Sensing Research Group, School of Automation and Electrical Engineering, Qingdao \\ University, Postcode: 266071, Shandong Province, Qingdao, P.R. China
}

Correspondence: Gerard Rushingabigwi, Email: g.rushingabigwi@ gmail.com

\begin{abstract}
The desert's dust and anthropogenic biomass burning's black carbon (BC) in the tropical regions are associated with many effects on climate and air quality. The dust and BC are the selected aerosols, which affect health by polluting the breathable air. This research discusses the effects of both the aerosols, especially while they interact with the clouds. The respective aerosol extinction optical thickness (AOT) extinction was analysed with the sensible heat from Turbulence. The research purposes to quantitatively study the remote sensing data for fine particulate matter, $\mathrm{PM}_{2.5}$, heterogeneously mixing both the dust and the pulverized black carbon's soot or ash, to analyse at which levels $\mathrm{PM}_{2.5}$ can endanger human health in the subSaharan region. The mainly analysed data had been assimilated from different remote sensing tools; the Goddard interactive online visualization and analys is infrastructure (GIOVANNI) was in the centre of data collection; GIS, the research data analys is software. In results, the rise and fall of the averaged sensible heat were associated with the rise and fall of averaged aerosol extinction AOT; the direct effects of the selected aerosols on the clouds are also presented. Regarding the health effects, $\mathrm{PM}_{2.5}$ quantities are throughout beyond the tolerably recommended quantity of $25 \mu \mathrm{g} / \mathrm{m}^{3}$; thus, having referred to erstwhile research, inhabitants would consume food and drug supplements which contain vanillic acid during dusty seasons.
\end{abstract}

Keywords: Geographic Information System (GIS), remotely sensed data, spatio-temporal (data) analysis

\section{Introduction}

The dust from deserts has been the biggest source of air polluting particulates, and the effects of dust aerosol are many (Hamdan et al, 2018; Osada et al., 2014; Varga, 2012). Aerosols are more dangerous, and the most particular is the particulate matter (PM) (Aneja et al, 2012; Costa et al., 2012; Fullová et al, 2017; Grahame and Schlesinger, 2005; Hamdan et al., 2018; Hu et al., 2016; Kantová et al, 2017; Tsui et al., 2018; Yu et al, 2017). The literature reiterates that the dust and particulate matter play a vital role to characterize and control the global air pollution (Kassomenos et al., 2012; Salvador et al., 2013; Tsui et al., 2018). Besides, the quantification of Energy balance on earth goes with climate change prediction-(Ackerman et al., 2018). 
With a reference to Shine, (2000), the remote sensing's extinction is explained as a phenomenon of losing some photon energy through scattering and absorption of that energy. In remote sensing, the aerosol optical thickness (AOT), sometimes referred to as Aerosol Optical Depth (AOD), is distributed within a column of air to the top of the atmosphere (Holben et al., 1998; Rushingabigwi et al., 2019).

The burnt biomass together with fine PM from both deserts and men's activities, globally pollute the atmospheric air (Chen et al., 2017). The smoke as a gaseous aerosol broadly links with the ecosystem, to mean the living organisms and non-living entities like atmospheric air as well as cloud and climate. The global air-polluting particles come from both the discipline of aerosols and atmospheric chemistry.

In this research, the selected particles are the dust's fine particulate matter $\left(\mathrm{PM}_{2.5}\right)$ as well as Black Carbon (BC), which highly contribute to air pollution parameters. The dust belt, according to Varga (2012), as cited (Middleton \& Kang, 2017), as well as meningitis belt (Thomson et al., 2013), which keep expanding, made the continent of Africa a most reported research area for the source of different sized particulate matter, $\mathrm{PM}\left(\mathrm{PM}_{1}, \mathrm{PM}_{2.5}, \mathrm{PM}_{10}\right)$ which are classified under solid aerosols (Goix et al., 2016).

To rationalize the present research, aerosol science has been so neglected that until the 1980s most people did not pay much attention to the hazards of aerosols to human breathing and blood circulation (Han, 2012). For instance, cardiovascular problems and death caused by air pollution are globally reported, and more deaths are of air pollution when compared to deaths due to viral diseases (Guo et al., 2018).

Regarding the on-site (in situ) versus remote sensing data collection, it has been clarified that data collected in the field is only convenient in case of physical, biological, and social science research. However, in the case of air pollution and other scientific research works that cover the vast geographical areas, yet with accuracy and consistency, remote sensing data is better than in situ data (Jensen, 2011).

The research motivation came from reading the literature in the same research area and found that there exist very limited similar research works and publications done in Africa. Moreover, the present research objectives contain the uniqueness and added-value, whereby studying aerosol and air quality would excite the awareness of people towards the sustained life, with an eye on the global deserts dust-belt (Rushingabigwi et al., 2019, p. 1955). This research aimed at demonstrating the direct effects of the selected aerosols to the sensible heat from Turbulence, to Cloud cover, and to the human health, by focusing on Africa; showing, by results, the quantitative analysis of $\mathrm{PM}_{2.5}$ levels based on five subdivisions in Africa; and discussing both the polluting and direct link with the sustainability of the ecology.

\section{Materials and Methods}

\subsection{The res earch data source}

Remotely sensed data from the Earth observation's instruments such as the Moderate-resolution Imaging Spectro-radiometer (MODIS), is globally documentable, but it's challenging to identify remote sensors which can directly detect the dust and the particulate matter (Madhavan, Qu, \& 
Hao, 2017). Thus, the raw data for this research was collected from the second version of modern-era retrospective analysis for research and applications (MERRA-2), an online model which directly incorporates the MODIS, the advanced very high-resolution radiometer (AVHRR) as well as the Aerosol Robotic Networks (AERONETS) remote sensing data (Rienecker et al., 2011).

\subsection{Research Method's Roadmap}

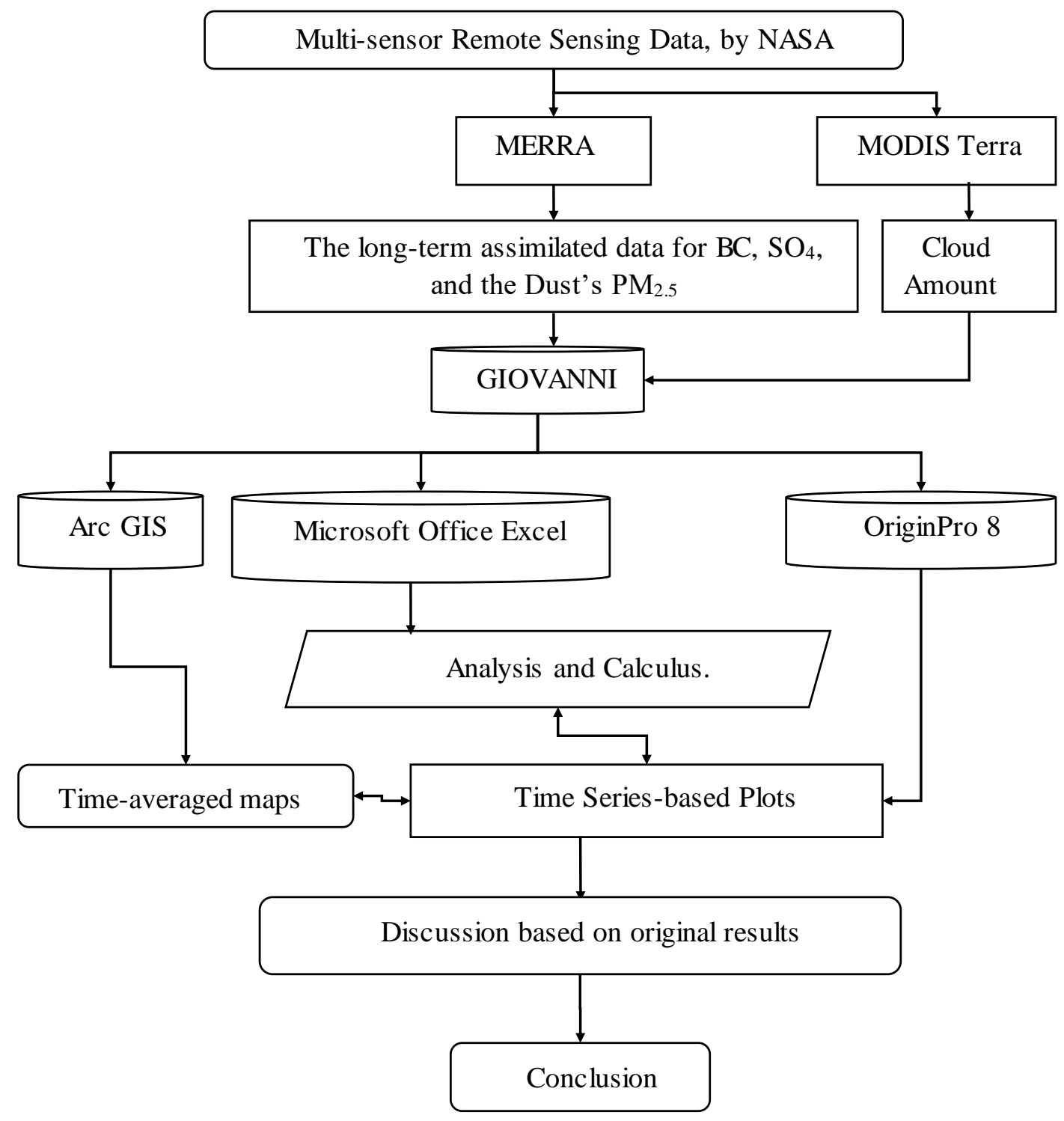

Figure 1: The research roadmap

As shown in Figure 1, GIOVANNI (Goddard interactive online visualization and analysis infrastructure), is a central platform for this research. Most of the data is collected from MERRA-2, an existing Model with most update algorithm (GES-DISC, 2019), and where needed, specific data (an example of the cloud amount) was collected from the specific remote sensor, such as MODIS-Terra.

Depending on the design of research, the computational analyses were conducted at the level of GIOVANNI platform (Leptoukh, 2011; Acker et al., 2014), and all the results presented in this 
research article have been certainly readjusted by the help of Arch GIS and Origins as software tools. More details about GIOVANNI, for the new users, can be documented online (GESDISC, 2019).

\section{The discussed results}

As results are presented and discussed in this research, the seasonal naming is such that:

○ DJF means December, January, and February;

○ MAM stands for March, April, and May;

○ JJA is for June, July, and August;

○ SON, for September, October, and November.

\subsection{Results in entire Africa}

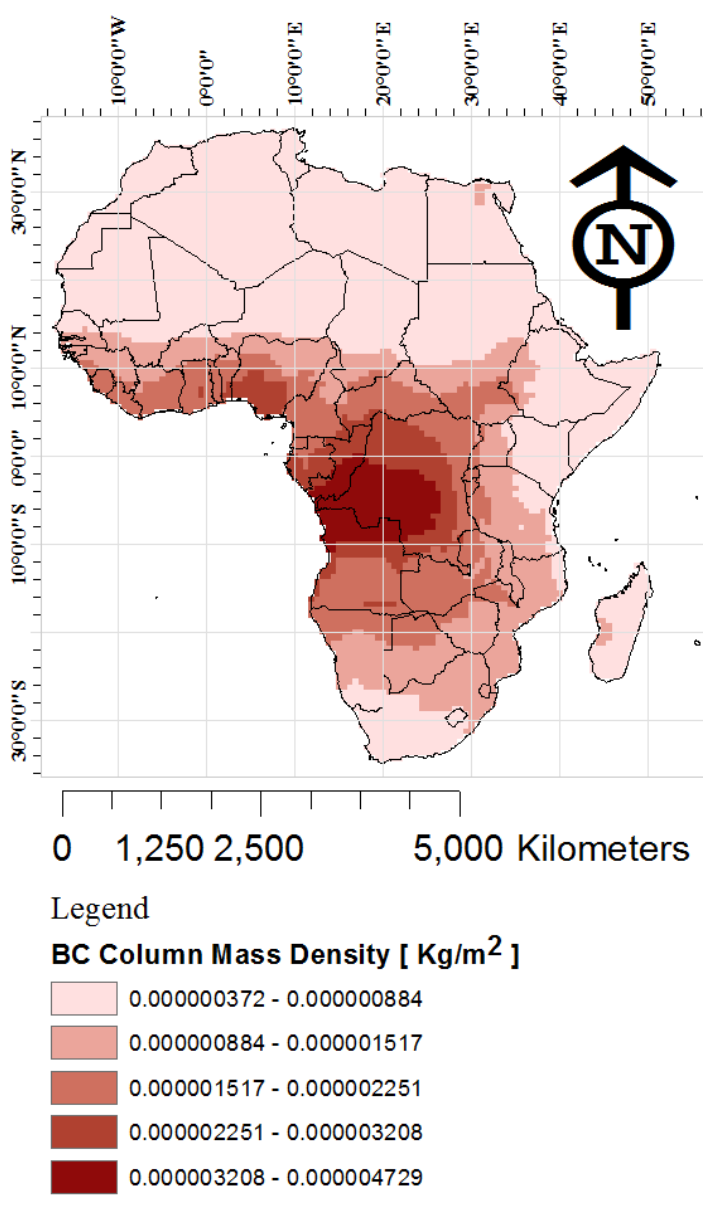

(a)

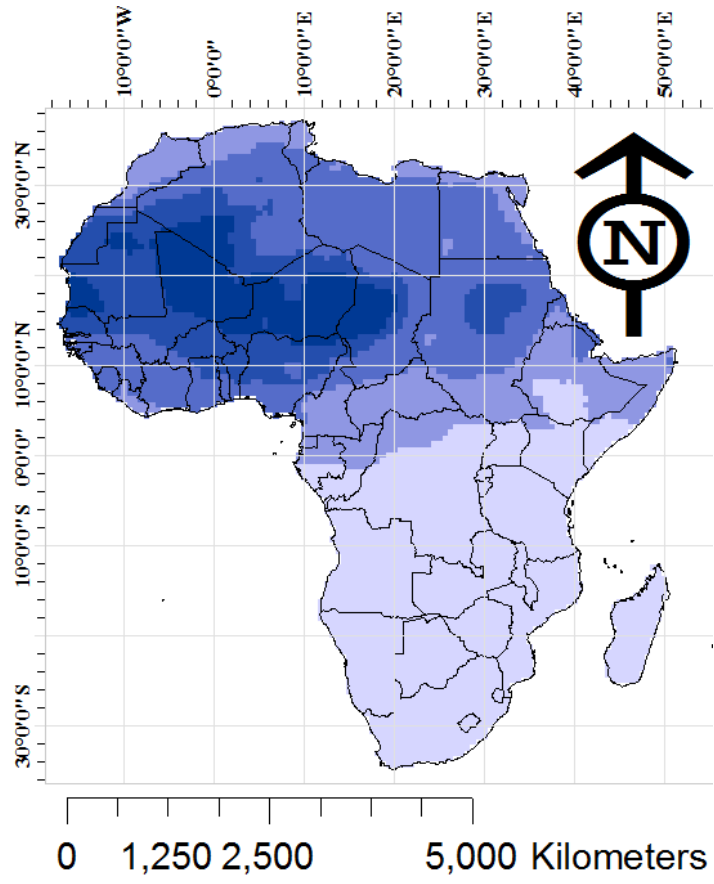

Legend

Dust Column Mass Density [ $\mathrm{Kg} / \mathrm{m}^{2}$ ]

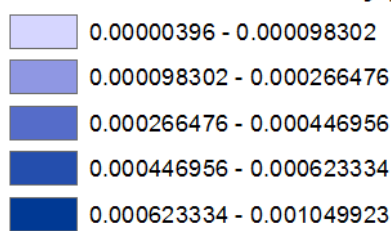

(b)

Figure 2: Africa's time-averaged Map for the Column Mass Density, from January 2000 to September 2019: (a) Dust aerosol; (b) BC aerosol [Source of the Raw data: GES DISC (2019)]

As shown in Figure 2 (a), the heaviest dust mass column in the troposphere of northern Africa, containing the Desert of Sahara, while Figure 2(b) shows the heaviest BC mass column density in mid-latitude Africa. Figure 2 just gives the overview; the next results are presented in the format of times series, just for more details. 


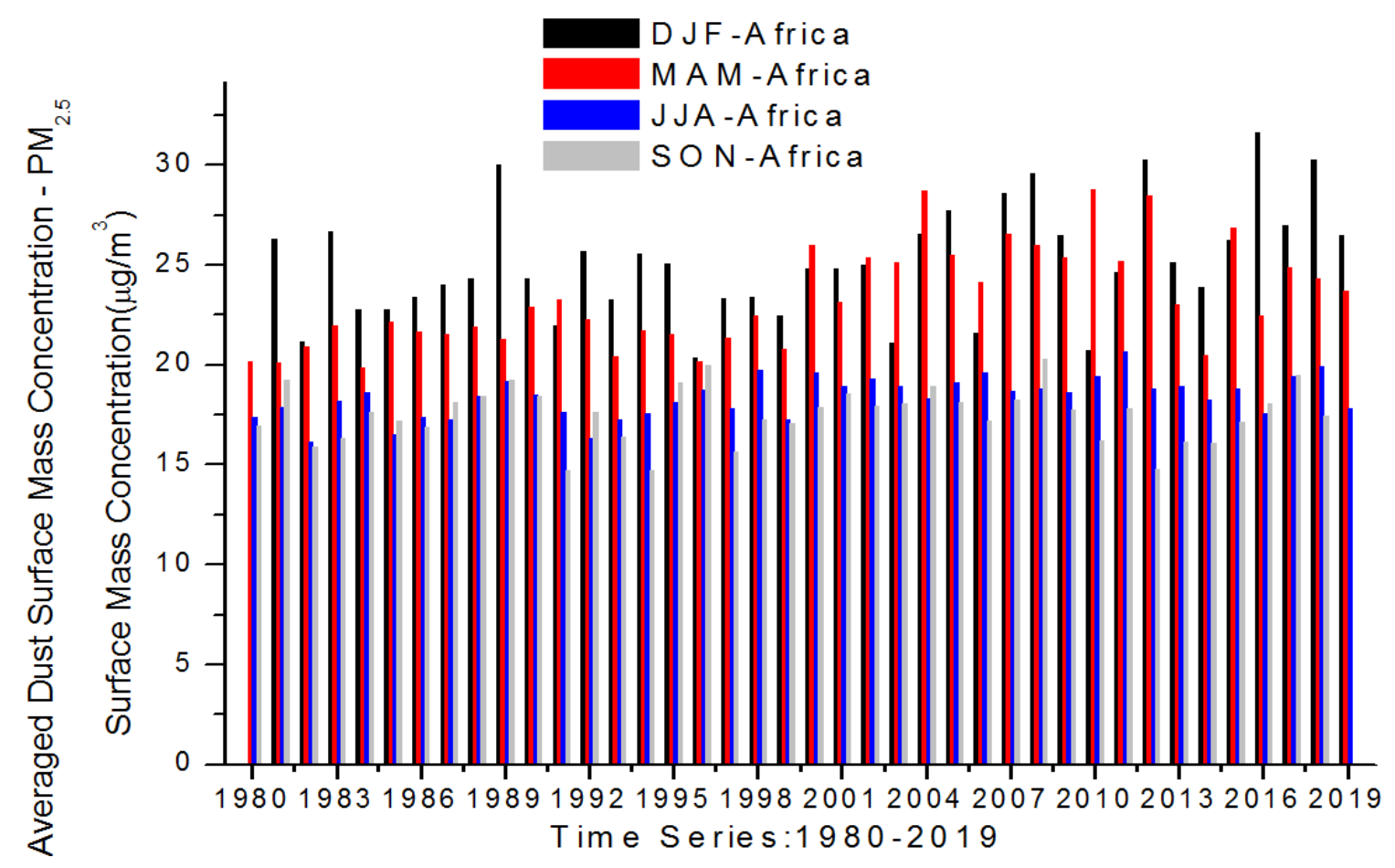

(a)

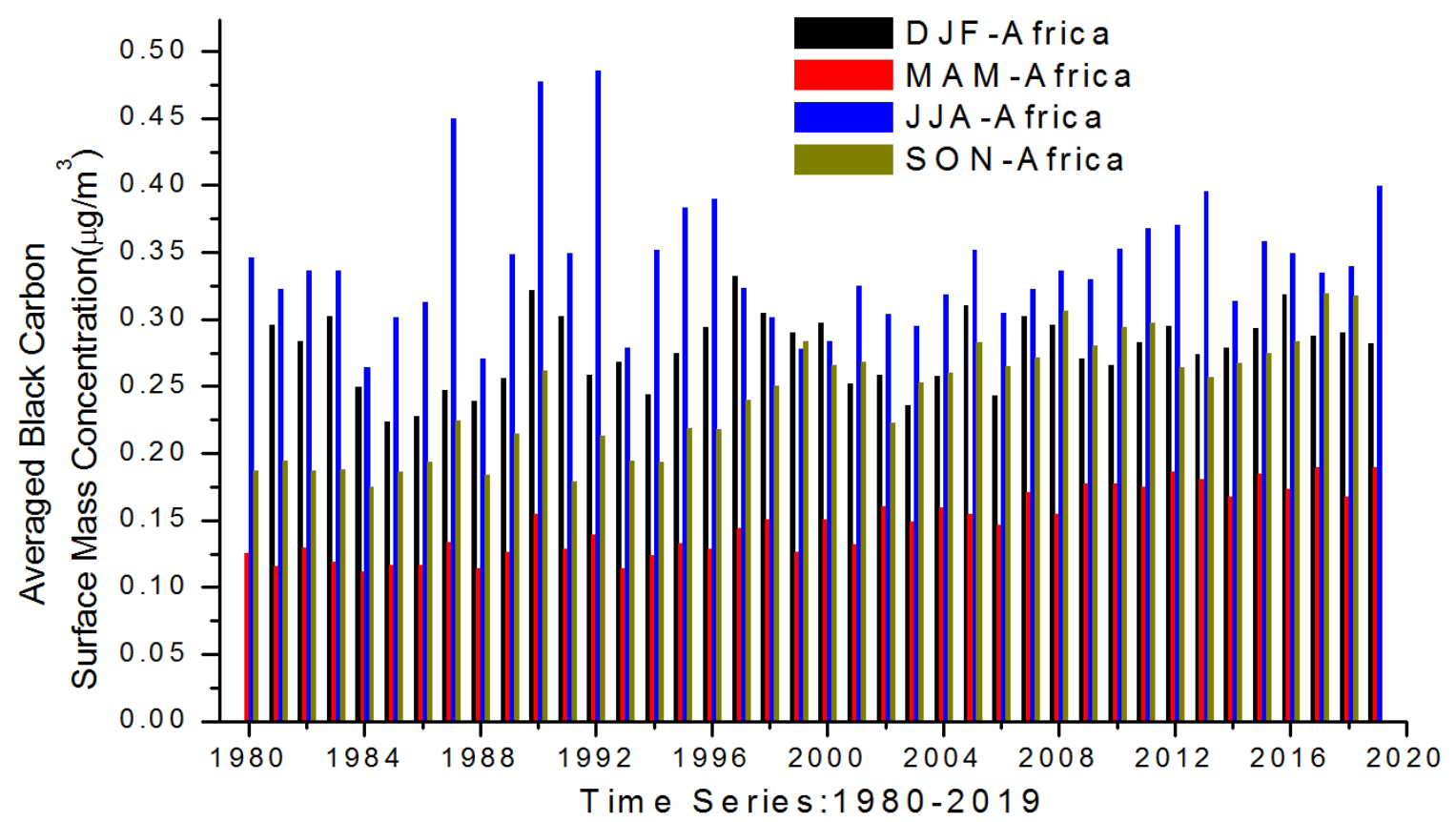

(b)

Figure 3: The long-term and averaged time-series of the Surface Mass Concentration in entire Africa for (a) the Dust's PM 2.5 monthly, (b) Black Carbon [Source of the Raw data: GES DISC (2019)]

\subsection{Results based on sub-spatial res olutions in Africa}

With knowledge of the African Physical Geography as well as climates, five sub-regions had been created and those are described:

- $15^{\circ} \mathrm{W}, 9.5^{\circ} \mathrm{E},(4-14)^{\circ} \mathrm{N}$ for West Africa;

- $10^{\circ} \mathrm{W}, 52^{\circ} \mathrm{E},(24-40)^{\circ} \mathrm{N}$ for the North Africa and neighbourhood; 
- $(9.5-30)^{\circ} \mathrm{E}, 10^{\circ} \mathrm{S}, 14^{\circ} \mathrm{N}$ for Central Africa;

- $(11-35)^{\circ} \mathrm{E},(10-35)^{\mathrm{o}} \mathrm{S}$ for South Africa;

- $(30-52)^{\circ}$ E, $28^{\circ} \mathrm{S}, 12^{\circ} \mathrm{N}$ for East Africa.

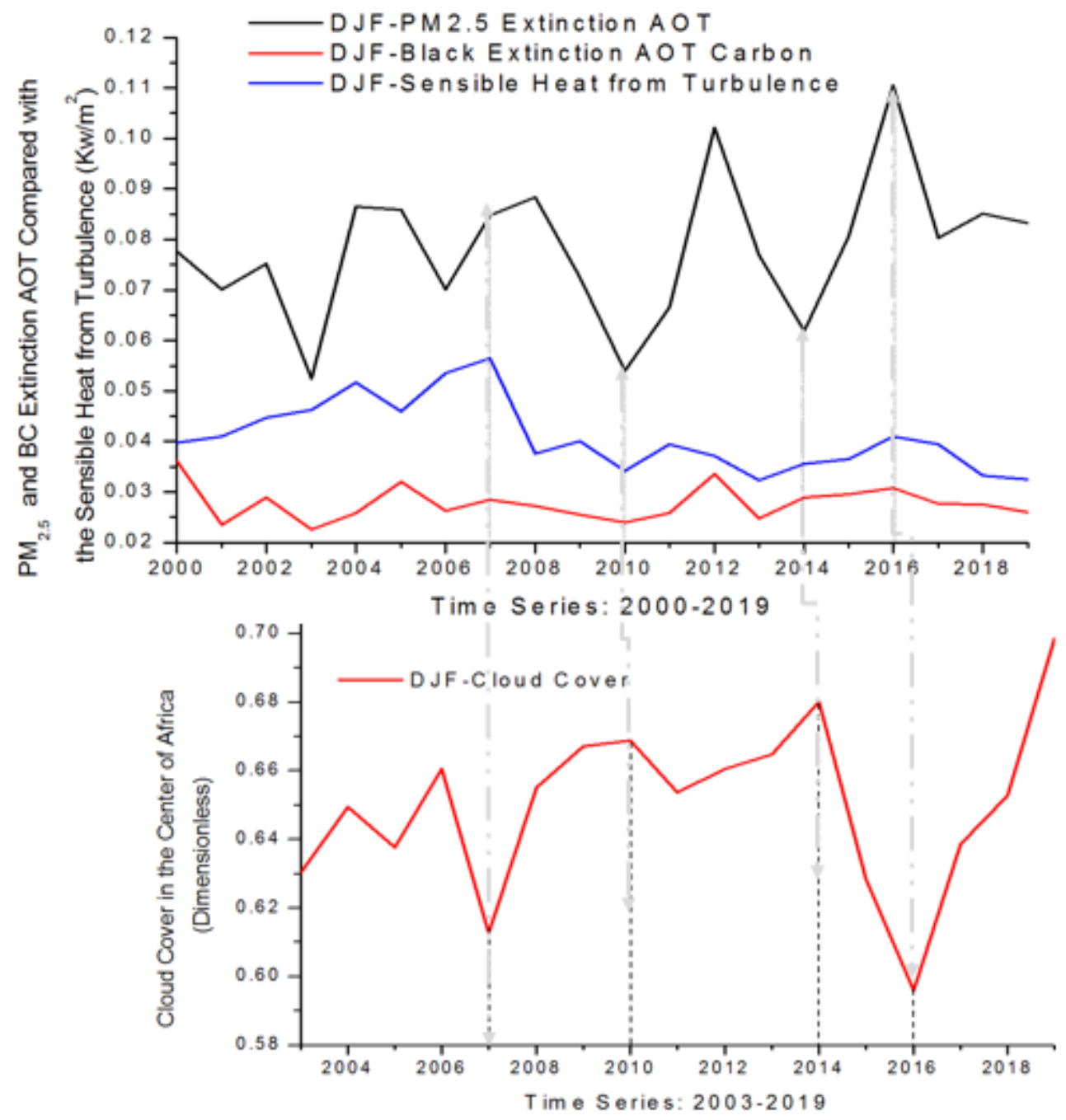

Figure 4: The relationship between the particulate matter $\left(\mathrm{PM}_{2.5}\right)$, the BCExtinction AOT, the sensible heat energy from turbulence as well as the Cloud Cover: aerosols' effects on climate change in the centre of the region of interest, over JJA Seasons. [Source of the Raw data: GES DISC (2019)] 


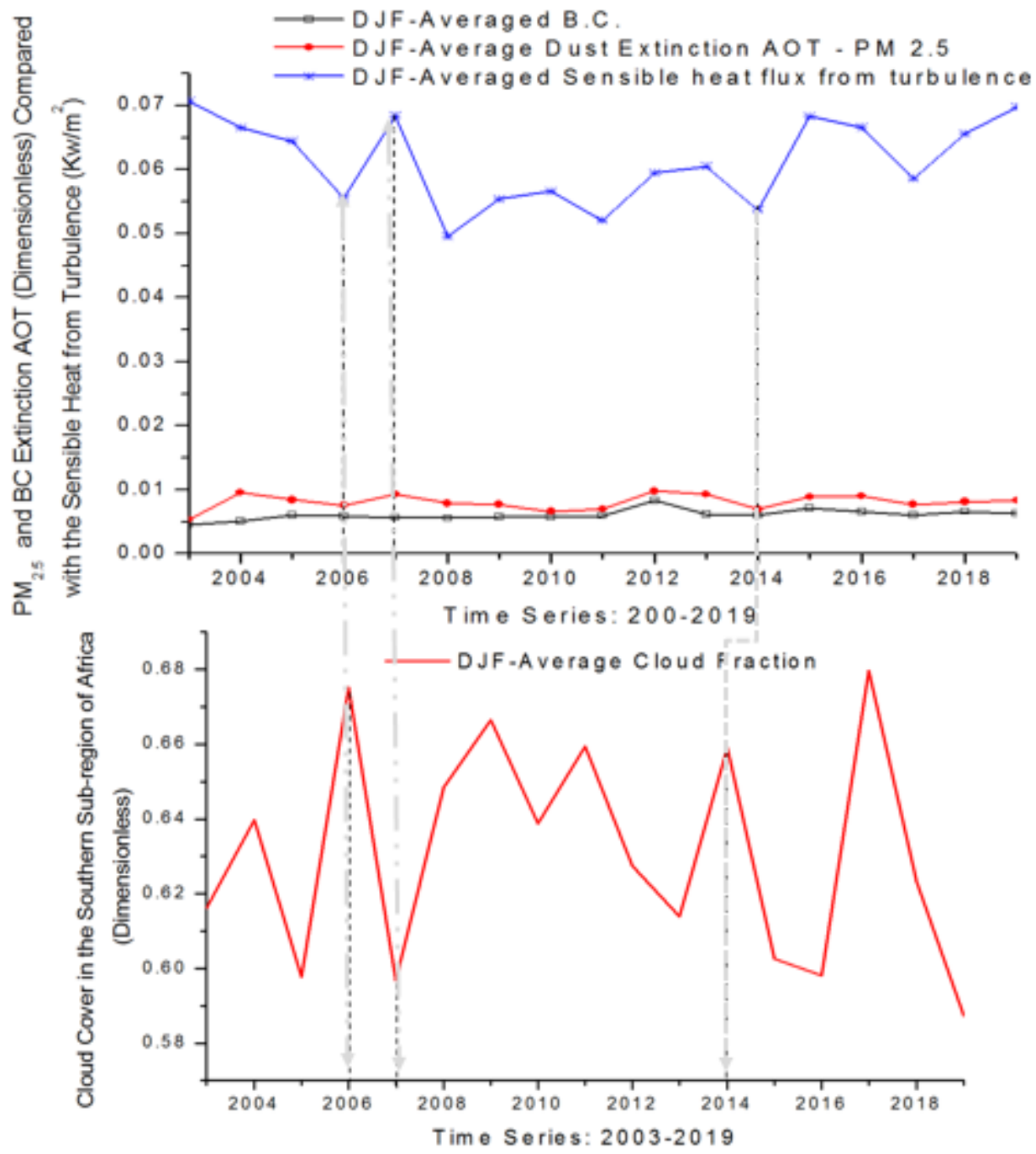

Figure 5. The relationship between the particulate matter $\left(\mathrm{PM}_{2.5}\right)$, the BC Extinction AOT, the sensible heat energy from turbulence as well as the Cloud Cover: aerosols' effects on climate change in the centre of the region of interest, over JJA Seasons. [Source of the Raw data: GES DISC (2019)]

\section{Discussion}

From Figure 2, the most central sub-region of Africa can be an important focal region to study the effects of the dust aerosol from the Sahara Desert as well as Black Carbon resulting from the mid-latitudes Africa; northern Africa is dominated by the dust from the Sahara Desert. With a reference made to Figure 3, the surface mass concentration of the dust aerosol extremely heavier that $\mathrm{BC}, \mathrm{DJF}$ and MAM are the African seasons with the heaviest dust in the atmosphere. This research selected the central sub-region to be the focal region of interest to study the possible relationship between the increase/decrease of the two selected aerosols with that (increase/decrease) of the sensible heat from turbulence. 
Table 1: The dust's $\mathrm{PM}_{2.5}$ concentration $\left(\mu \mathrm{g} / \mathrm{m}^{3}\right)$, in the sub-divided Africa [Source of the Raw data: GES DISC (2019)]

\begin{tabular}{|c|c|c|c|c|c|c|c|c|c|c|c|c|}
\hline \multirow[b]{2}{*}{ TIME } & \multicolumn{4}{|c|}{ West-Africa } & \multicolumn{4}{|c|}{ North-Africa } & \multicolumn{4}{|c|}{ Central-Africa } \\
\hline & $\overline{\mathrm{DJF}}$ & MAM & JJA & SON & DJF & MAM J & JJA & SON & DJF & MAM & JJA & SON \\
\hline 2000 & 66.8 & 54 & 9.4 & 21.1 & 25.3 & \begin{tabular}{|ll}
$3 \quad 40.9$
\end{tabular} & 39.1 & 133.3 & 34.4 & 24.6 & $\begin{array}{ll}6 & 6.1\end{array}$ & 11.3 \\
\hline 2001 & 69 & 38.8 & 9.3 & 26.9 & 29.1 & 39.8 & 39.1 & 33.4 & 31.6 & 21.1 & 5.9 & 12.0 \\
\hline 2002 & 67.2 & 46 & 9.7 & 21.4 & 28.9 & 43.3 & 38.9 & 33.3 & 32.7 & 23.8 & 6.4 & 11.9 \\
\hline 2003 & 45.1 & 43.2 & 9.1 & 18.3 & 31.3 & 42.8 & 37.6 & 35.5 & 23.3 & 25.9 & 6.2 & 11.2 \\
\hline 2004 & 74.2 & 60.7 & 10 & 25.7 & 34.2 & 46.5 & 36.6 & 34.1 & 35.6 & 36.3 & 6.6 & 14.4 \\
\hline 2005 & 75.6 & 44.8 & 9.5 & 23.7 & 36.4 & 43.9 & 38.6 & 33 & 34.2 & 26.2 & 6.7 & 12.5 \\
\hline 2006 & 36.9 & 47.9 & 11.8 & 25.2 & 33.5 & 40 & 40.4 & 30.3 & 26.3 & 26.1 & 6.9 & 12.2 \\
\hline 2007 & 84.6 & 54.1 & 8.4 & 26.1 & 31.6 & 44 & 39.4 & 32.3 & 35.4 & 27.7 & 5.7 & 13.4 \\
\hline 2008 & 85.2 & 44.9 & 7.9 & 29.4 & 32.3 & 47.8 & 40.7 & 37.4 & 38.4 & 22.7 & 5.0 & 12.8 \\
\hline 2009 & 59.1 & 42.2 & 9.2 & 25.2 & 39.1 & 42.3 & 37.3 & 31.6 & 29.9 & 27.9 & 6.1 & 12.7 \\
\hline 2010 & 37.2 & 56 & 10.6 & 16.8 & 38.6 & 47.8 & 38.3 & 33.6 & 22.1 & 26.1 & 6.3 & 9.0 \\
\hline 2011 & 58.8 & 37.8 & 12.2 & 22 & 34.4 & 42.9 & 40.3 & 31.5 & 28.7 & 25.5 & 12.2 & 12.7 \\
\hline 2012 & 77.1 & 53.9 & 9.2 & 15.6 & 34.7 & 43.2 & 36.8 & 28.3 & 40.0 & $30 .($ & 6.2 & 9.6 \\
\hline 2013 & 57 & 25.4 & 8.4 & 16.5 & 33.2 & 46.1 & 38.9 & 30.3 & 32.0 & 20.1 & 5.6 & 10.5 \\
\hline 2014 & 52.3 & 29.5 & 8.8 & 17 & 31.6 & 36.8 & 37.5 & 31.6 & 27.0 & 19. & 5.4 & 10.3 \\
\hline 2015 & 62.9 & 54.5 & 11 & 24.2 & 34.3 & 38.7 & 37.8 & 30.3 & 33.6 & 33.7 & 6.5 & 11.0 \\
\hline 2016 & 108.3 & 29 & 7.9 & 28.5 & 28 & 40.2 & 36.2 & 31.4 & 46.1 & 21.8 & 5.2 & 13.0 \\
\hline 2017 & 67.2 & 41.3 & 14.1 & 36.5 & 30.8 & 41.8 & 36.3 & 30.5 & 36.8 & 27.1 & 9.4 & 17.5 \\
\hline 2018 & 85.1 & 39.7 & 14.4 & 24.3 & 37 & 46.4 & 37.8 & 32 & 36.4 & 26.0 & 7.1 & 11.4 \\
\hline 2019 & 63.6 & 41.3 & 10.9 & N/A & 32.4 & 39 & 35.1 & N/A & 37.0 & 25.5 & 6.1 & N/A \\
\hline & \multicolumn{4}{|c|}{ East-Africa } & \multicolumn{4}{|c|}{ South-Africa } & & & & \\
\hline TIME & JJA & $\mathrm{SON}$ & JJA & SON & JJA & SON & JJA & SON & & & & \\
\hline 2000 & 4.5 & 4.6 & 3.7 & 2.5 & 1.6 & 1.8 & 2.1 & 2.1 & & & & \\
\hline 2001 & 5.1 & 4.0 & 3.5 & 2.6 & 2.4 & 1.5 & 1.8 & 1.7 & & & & \\
\hline 2002 & 5.1 & 3.8 & 4.0 & 2.7 & 2.2 & 1.3 & 1.8 & 1.8 & & & & \\
\hline 2003 & 3.7 & 4.6 & 3.8 & 2.7 & 1.6 & 1.5 & 1.8 & 2.0 & & & & \\
\hline 2004 & 5.2 & 5.1 & 3.7 & 2.7 & 2.7 & 2.4 & 1.9 & 1.8 & & & & \\
\hline 2005 & 4.6 & 3.7 & 3.9 & 2.8 & 2.2 & 1.7 & 1.6 & 1.9 & & & & \\
\hline 2006 & 4.3 & 4.4 & 3.8 & 2.6 & 2.0 & 1.6 & 1.9 & 1.8 & & & & \\
\hline 2007 & 5.8 & 4.3 & 3.5 & 3.3 & 2.6 & 1.8 & 1.9 & 2.2 & & & & \\
\hline 2008 & 7.3 & 4.6 & 4.0 & 3.6 & 2.2 & 1.3 & 1.6 & 2.1 & & & & \\
\hline 2009 & 5.4 & 5.0 & 3.9 & 2.9 & 2.2 & 1.5 & 1.9 & 1.8 & & & & \\
\hline 2010 & 4.5 & 4.5 & 3.8 & 3.2 & 2.0 & 1.5 & 1.9 & 2.0 & & & & \\
\hline 2011 & 5.6 & 4.3 & 6.3 & 3.5 & 2.0 & 1.3 & 1.9 & 2.1 & & & & \\
\hline 2012 & 7.8 & 6.6 & 4.5 & 3.0 & 2.7 & 1.8 & 1.9 & 2.0 & & & & \\
\hline 2013 & 5.6 & 4.1 & 4.3 & 2.9 & 2.6 & 1.7 & 1.8 & 2.0 & & & & \\
\hline 2014 & 5.7 & 3.3 & 3.9 & 2.8 & 2.1 & 1.6 & 1.9 & 1.9 & & & & \\
\hline 2015 & 5.8 & 4.8 & 4.1 & 2.7 & 2.7 & 1.6 & 1.6 & 2.0 & & & & \\
\hline 2016 & 6.5 & 3.8 & 3.8 & 3.2 & 2.7 & 1.7 & 1.7 & 1.9 & & & & \\
\hline 2017 & 5.5 & 4.5 & 4.9 & 3.4 & 2.3 & 1.5 & 1.5 & 1.7 & & & & \\
\hline 2018 & 6.8 & 4.9 & 5.3 & 2.9 & 2.4 & 1.8 & 2.1 & 1.9 & & & & \\
\hline 2019 & 5.2 & 4.3 & 3.9 & N/A & 2.5 & 1.8 & 1.7 & N/A & & & & \\
\hline
\end{tabular}

Besides, the dust can cause tuberculos is (Wang et al., 2016) as well as meningitis (Agier et al., 2017). It had been argued that $\mathrm{PM}_{2.5}$ is a heterogeneous mixture that includes desert's dust and 
carbonaceous emissions from combustion and wildland fire (Rushingabigwi et al., 2020), the quantitative results in Table 1 show the dust's $\mathrm{PM}_{2.5}$ in all the 5 sub-regions, and the annuallyaveraged mass concentration of the dust's $\mathrm{PM}_{2.5}$ is throughout greater than the mean value, $25 \mu \mathrm{g} / \mathrm{m}^{3}$ (Chen et al., 2017). The extremely high levels are experienced in the DJF and MAM seasons of the West, North, and Central Africa. Other regions and seasons with high, and low values are found in Table 1 too.

The possible reason for Africa's increasing dust aerosol might be due to the vastest global Desert of Sahara which keeps expanding (Thomas and Nigam, 2018); while the increasing BC aerosol in the Centre of Africa is the results of biomass burning activities, the anthropogenic activities are certain in mid-latitudes of the earth (Chen et al., 2017). Figure 4 and Figure 5 clarify, in a season of DJF (selected for the heaviest dust) for the selected sub-spatial resolutions, that the increase of the selected aerosols is directly proportional to the increase of the sensible heat from turbulence and the decrease of the cloud amount.

The long-term exposure to $\mathrm{PM}_{2.5}$ was most strongly associated with mortality attributable to cardiac dysrhythmias, ischemic heart diseases, cardiac arrest, and heart failure, that's according to Dianat et al. (2016). We would then suggest the consumption of food supplements which contain vanillic acid during dust event seasons. Green tea is an example, which contains a lot of catechins, one of the natural antioxidants too (Pietta, et al., 1998).

\section{Conclusion}

The results presented in different formats in this research demonstrate the effects of aerosols on climate change by directly attenuating the cloud amount and increasing the sensible heat energy whenever the aerosols volumes had increased. An important point to mention, and which can be projected to further research is that the Winter (DJF) and spring (MAM) of the West and Central Africa have been characterized by the heaviest surface mass concentration of dust's fine particulate matter. Over the 19 years, selected for the remote sensing data analys is, the quantities of $\mathrm{PM}_{2.5}$ are throughout beyond the tolerably recommended quantity of $25 \mu \mathrm{g} / \mathrm{m}^{3}$, further investigations are recommended to demonstrate how it can be linked with the Sub-Saharan meningitis belt. The consumption of food and drug supplements which contain vanillic acid during dusty seasons is also recommended.

\section{Acknowledgments}

The endeavors of NASA's Goddard Earth Sciences Data and Information Services Center (GES DISC) are much acknowledgeable: GIOVANNI platform is regularly updated for research purposes. We can't forget the supports by the University of Rwanda, for the finance and time put in research and innovation, to sustain the academic staff growth and development.

\section{References}

Ackerman, S. A., Platnick, S., Bhartia, P. K., Duncan, B., L'Ecuyer, T., Heidinger, A., Smith, N. (2018). Satellites See the World's Atmosphere. Meteorological Monographs, 59, 4.1-4.53. https://doi.org/10.1175/ams monographs-d-18-0009.1 
Acker, J., Soebiyanto, R., Kiang, R., Kempler, S., 2014. Use of the NASA Giovanni data system for geospatial public health research: example of weather-influenza connection. ISPRS Int. J. Geo-Inf. 3, 1372-1386. https://doi.org/10.3390/ijgi3041372.

Agier, L., Martiny, N., Thiongane, O., Mueller, J. E., Paireau, J., Watkins, E. R., Broutin, H. (2017). Towards understanding the epidemiology of Neisseria meningitidis in the African meningitis belt: a multi-disciplinary overview. International Journal of Infectious Diseases, 54, 103-112. https://doi.org/10.1016/j.ijid.2016.10.032

Aneja, V. P., Isherwood, A., \& Morgan, P. (2012). Characterization of particulate matter (PM10) related to surface coal mining operations in Appalachia. Atmospheric Environment, 54, 496-501. https://doi.org/10.1016/j.atmosenv.2012.02.063

Chen, J., Li, C., Ristovski, Z., Milic, A., Gu, Y., Islam, M. S., Dumka, U. C. (2017). A review of biomass burning: Emissions and impacts on air quality, health, and climate in China. Science of the Total Environment, 579 (November 2016), 1000-1034. https://doi.org/10.1016/j.scitotenv.2016.11.025

Costa, M. A. M., Carvalho, J. A., Soares Neto, T. G., Anselmo, E., Lima, B. A., Kura, L. T. U., \& Santos, J. C. (2012). Real-time sampling of particulate matter smaller than $2.5 \mu \mathrm{m}$ from Amazon forest biomass combustion. Atmospheric Environment, 54, 480-489. https://doi.org/10.1016/j.atmosenv.2012.02.023

Han, D. (2012). Air Pollution, in Concise Environmental Engineering, ch.9, pp.109-120, Booboon.com

Dianat, M., Radmanesh, E., Badavi, M., Mard, S. A., and Goudarzi, G. (2016). Disturbance effects of PM10 on iNOS and eNOS mRNA expression levels and antioxidant activity induced by ischemia-reperfusion injury in isolated rat heart: protective role of vanillic acid. Environ Sci Pollut Res (2016) 23, 5154-5165. https://doi.org/10.1007/s11356-015-5759-x

Fullová, D., Durčanská, D., \& Hegrová, J. (2017). Impact of Asphalt Mixture Composition on Particulate Matter Production. Procedia Engineering, 192, 201-206. https://doi.org/10.1016/j.proeng.2017.06.035

Goix, S., Uzu, G., Oliva, P., Barraza, F., Calas, A., Castet, S., Gardon, J. (2016). Metal concentration and bioaccessibility in different particle sizes of dust and aerosols to refine metal exposure assessment. Journal of Hazardous Materials, 317, 552-562. https://doi.org/10.1016/j.jha zmat.2016.05.083

Grahame, T. J., \& Schlesinger, R. B. (2005). Evaluating the health risk from secondary sulfates in eastern North American regional ambient air particulate matter. Inhalation Toxicology, 17(1), 15-27. https://doi.org/10.1080/08958370590885672

GES DISC (2019). Giovanni, the Bridge between Data and Science, version 4.28 [text]. Retrieved from https://giovanni.gsfc.nasa.gov/giovanni/ (last visited on 14 November 2019).

Guo, H., Huang, S., \& Chen, M. (2018). Air pollutants and asthma patient visits: Indication of source influence. Science of the Total Environment, 625, 355-362. https://doi.org/10.1016/j.scitotenv.2017.12.298 
Hamdan, N. M., Alawadhi, H., Jisrawi, N., \& Shameer, M. (2018). Characterization of fine particulate matter in Sharjah, United Arab Emirates using comple mentary experimental techniques. Sustainability (Switzerland), 10(4). https://doi.org/10.3390/su10041088

Holben, B. N., Eck, T. F., Slutsker, I., Tanré, D., Buis, J. P., Setzer, A., Smirnov, A. (1998). AERONET-A Federated Instrument Network and Data Archive for Aerosol Characterization. Remote Sensing of Environment, 66(1), 1-16. https://doi.org/10.1016/S0034-4257(98)00031-5

Hu, W., Niu, H., Zhang, D., Wu, Z., Chen, C., Wu, Y., Hu, M. (2016). Insights into a dust event transported through Beijing in spring 2012: Morphology, chemical composition, and impact on surface aerosols. Science of the Total Environment, 565, 287-298. https://doi.org/10.1016/j.scitotenv.2016.04.175

Jensen, J. R. (2011). Remote Sensing of the Environment, in Remote Sensing of the Environment: An Earth Resource Perspective, 2nd Edition, ch.1. Pearson Education, Inc.

Kantová, N., Holubčík, M., Jandačka, J., \& Čaja, A. (2017). Comparison of Particulate Matters Properties from Combustion of Wood Biomass and Brown Coal. Procedia Engineering, 192, 416-420. https://doi.org/10.1016/j.proeng.2017.06.072

Kassomenos, P., Vardoulakis, S., Chaloulakou, A., Grivas, G., Borge, R., \& Lumbreras, J. (2012). Levels, sources, and seasonality of coarse particles (PM 10 - PM 2.5) in three European capitals - Implications for particulate pollution control. Atmospheric Environment, 54,337-347. https://doi. org/10.1016/j.atmosenv.2012.02.051

Leptoukh, G., 2011. Many faces of Giovanni. Last accessed on 20/09/2019, online. https://www.slideserve.com/benjy/many-faces-of-giovanni.

Madhavan, S., Qu, J. J., \& Hao, X. (2017). Saharan dust detection using multi-sensor satellite measurements. Heliyon, 3(2), e00241. https://doi. org/10.1016/j. heliyon.2017.e00241

Middleton, N., \& Kang, U. (2017). Sand and dust storms: Impact mitigation. Sustainability (Switzerland), 9(6), 1-22. https://doi.org/10.3390/su9061053

Osada, K., Ura, S., Kagawa, M., Mikami, M., Tanaka, T. Y., Matoba, S., Uematsu, M. (2014). Wet and dry deposition of mineral dust particles in Japan: Factors related to temporal variation and spatial distribution. Atmospheric Chemistry and Physics, 14(2), 1107-1121. https://doi.org/10.5194/acp-14-1107-2014

Pietta, P. G.; Simonetti, P.; Gardana, C.; Brusamolino, A.; Morazzoni, P.; Bombardelli, E. (1998). Catechin metabolites after intake of green tea infusions. BioFactors. 8 (1-2), 111118. https://doi.org/10.1002/biof.5520080119. PMID 9699018.

Rienecker, M. M., Suarez, M. J., Gelaro, R., Todling, R., Bacme ister, J., Liu, E., Woollen, J. (2011). MERRA: NASA's modern-era retrospective analys is for research and applications. Journal of Climate, 24(14), 3624-3648. https://doi.org/10.1175/JCLI-D-11-00015. 1

Rushingabigwi, G., Nsengiyumva, P., Sibomana, L., Twizere, T., and Kalisa, W. (2020). Analys is of the atmospheric dust in Africa: The breathable dust's fine particulate matter PM2.5 in correlation with carbon monoxide. Elsevier, Atmospheric Environment 224 (2020) 117319, 1-9, https://doi.org/10.1016/j.atmosenv.2020.117319 
Rushingabigwi, G., Nsengiyumva, P., Twizere, C., Sibomana, L., Hanyurwimf ura, D., Zimulinda F., .... W. Kalisa. Remote Sensing Data Analysis for the Effects of Three Selected Aerosols on Both Energy Budgets and Health: A Case of South-West Asia, 2019 Photonics \& Electromagnetics Research Symposium (PIERS) - Fall , Xiamen, China, 17 20 Dec. 2019. http://dx.doi.org/10.1109/PIERS-Fall48861.2019.9021726

Salvador, P., Artíñano, B., Molero, F., Viana, M., Pey, J., Alastuey, A., \& Querol, X. (2013). African dust contribution to ambient aerosol levels across central Spain: Characterization of long-range transport episodes of desert dust. Atmospheric Research, 127, 117-129. https://doi.org/10.1016/j.atmosres.2011.12.011

Shine, K. P. (2000). Radiative forcing of climate change. Space Science Reviews, 94(1-2), 363373. https://doi.org/10.1023/A:1026752230256

Thomas, N., \& Nigam, S. (2018). Twentieth-century climate change over Africa: Seasonal hydroclimate trends and Sahara desert expansion. Journal of Climate, 31(9), 3349-3370. https://doi.org/10.1175/JCLI-D-17-0187.1

Thomson, M. C., Jancloes, M., Foundation, C., Nickovic, S., Storm, D., \& Advisory, W. (2013). Climate Science for Serving Society. (May 2014). https //doi.org/10.1007/978-94-0076692-1

Tsui, H. C., Chen, C. H., Wu, Y. H., Chiang, H. C., Chen, B. Y., \& Guo, Y. L. (2018). Lifetime exposure to particulate air pollutants is negatively associated with lung function in nonasthmatic children. Environmental Pollution, 236, 953-961. https://doi.org/10.1016/j.envpol. 2017.10.092

Wang, Y., Wang, R., Ming, J., Liu, G., Chen, T., Liu, X., Cheng, G. (2016). Effects of dust storm events on weekly clinic visits related to pulmonary tuberculosis disease in Minqin, China. Atmospheric Environment, 205-212. https://doi.org/10.1016/j.atmosenv.2015.12.041

Yu, L., Jia, J., Chen, S., Lu, Q., \& Feng, G. (2017). Characteristics of the Concentration Change of the Particulate Matter in the Indoor and Outdoor Existing Public Office Buildings. Procedia Engineering, 205, 3367-3372. https://doi.org/10.1016/j.proeng.2017.09.843 